\title{
KOMUNIKASI ANTAR BUDAYA DALAM ADAT PERKAWINAN JAWA (Pendekatan Gudykunst dan Kim dalam Adat Perkawinan Jawa Oleh Pasangan Berbeda Budaya di Bengkulu Utara)
}

\author{
KUNDORI \\ Ilmu Komunikasi Universitas Putera Batam \\ kundori@puterabatam.ac.id
}

\begin{abstract}
ABSTRAK
Penelitian ini bertujuan melihat komunikasi antar budaya (KAB) dalam prosesi perkawinan adat Jawa yang dilakukan oleh pasangan berbeda budaya, yang dianalisis menggunakan model Gudykunt dan Kim berdasarkan faktor budaya, sosiobudaya, psikobudaya dan lingkungan, selain itu penelitian ini ingin melihat teori Gudykunt dan Kim yang lebih dominan muncul. Penelitian ini menggunakan metode penelitian Deskriptif Kualitatif. Waktu dan tempat penelitian dilakukan di Bengkulu Utara tepatnya di Kecamatan Ketahun terfokus pada perkawianan beda budaya antara Jawa dengan Pekal dan Jawa dengan Batak. Temuan penelitian ini menunjukkan: Pertama, ditinjau dari aspek budaya, Perbedaan sikap terlihat menjadi sebuah kendala awal dalam berkomunikasi namun setelah adanya pemahaman yang diberikan seorang mediator akhirnya juga mereka memahaminya. Ditinjau dari Faktor Psikobudaya: hambatan ini timbul karena stereotip, etnosentrisme tentang masyarakat Jawa yang terlalu rumit dan terlalu banyak adat istiadat selain itu mereka etnis Jawa percaya dengan mitos, namun demikian faktor psikobudaya ini hanya sebatas pemikiran bukan dalam bentuk tindakan. Ditinjau dari Faktor Lingkungan: perbedaan lingkungan muncul dalam bentuk orientasi tentang waktu dan makna perkawinan. Teori Gudykunt dan Kim yang terdiri dari faktor budaya, sosiobudaya, psikobudaya dan lingkungan yang lebih dominan muncul dalam perkawinan beda budaya JawaPekal dan Jawa- Batak adalah faktor Piskobudaya, namun demikian faktor ini tidak pada intensitas negatif, selain itu mediator juga terlihat dalam proses perkawinan beda budaya ini dalam menjembatani proses berjalanya komunikasi tersebut.
\end{abstract}

Kata kunci: Komunikasi Antar Budaya, Perkawinan, Jawa, Batak dan Pekal.

\section{PENDAHULUAN}

Dewasa ini pernikahan antarbudaya sangat meningkat, menurut Tseng menyebutkan bahwa perkawinan antar etnis (intercultural marriage) adalah perkawinan yang terjadi antara pasangan yang berasal dari latar belakang budaya yang berbeda. Budaya menjadi suatu aspek yang penting dalam perkawinan, dimana pasangan tersebut tentu memiliki dalam hal nilai-nilai budaya yang dianut, menurut keyakinan dan kebiasaan, serta adat istiadat dan gaya hidup budaya. Menurut Koentjaraningrat di dalam perkawinan juga disatukan dua budaya yang berbeda, latar belakang yang berbeda, suku yang berbeda. Latar belakang yang berbeda ini dapat menimbulkan ketidakcocokan. Ketidak cocokan tersebut dapat mengakibatkan konflik, baik tentang kebiasaan, sikap perilaku 
dominan, maupun campur tangan keluarga, (Wahyudi, 2015:78).

Berdasarkan data perkara yang masuk di Pengadilan Agama Arga Makmur Kabupaten Bengkulu Utara tercatat 131 data perkara percerain selama bulan Juni, ini terlihat bahwa semakin banyaknya konflik dalam kehidupan rumah tangga yang pada ujungnya berakhir di Pengadilan Agama.(http://sipp.paargamakmur.go.id/statistik_perkara, diakses pada tanggal 2 Juni 2018).

Fokus penelitian ini adalah komunikasi antarbudaya dalam perkawinan etnis Jawa dengan menggunakan pendekatan model William B. Gudykunst dan Young Yun Kim (Mulyana, 2010: 170) dalam adat perkawinan jawa oleh pasangan berbeda budaya di Bengkulu Utara. Model ini mengasumsikan dua orang yang sejajar dalam berkomunikasi, masing-masing dari mereka sebagai pengirim sekaligus penerima atau keduanya sebagai penyandi (encoding) dan penyandi balik (decoding).

\section{Rumusan Masalah}

1. Bagaimana komunikasi antar budaya dalam prosesi perkawinan adat Jawa yang dilakukan oleh pasangan berbeda budaya dilihat dari Teori Gudykunt dan Kim di Kecamatan Katahun?

2. Teori Gudykunt dan Kim yang terdiri dari budaya, sosiobudaya, piskobudaya dan lingkungan manakah yang lebih dominan muncul dalam perkawinan adat Jawa di Kecamatan Katahun?

\section{Tujuan Penelitian}

- Untuk mengetahui bagaimana komunikasi antar budaya dalam prosesi perkawinan adat Jawa yang dilakukan oleh pasangan berbeda budaya dilihat dari Teori Gudykunt dan Kim di Kecamatan Ketahun.

- Untuk mengetahui Teori Gudykunt dan Kim yang terdiri dari budaya, sosiobudaya, piskobudaya dan lingkungan yang lebih dominan muncul dalam perkawinan adat Jawa di Kecamatan Ketahun.

\section{Kegunaan Penelitian}

\section{Kegunaan Teoritis}

- Sebagai bahan rujukan bagi peneliti sejenis dimasa yang akan datang dengan komunikasi antar budaya kususnya dan komunikasi pada umumnya serta studi tentang budaya Indonesia lainya.

\section{Kegunaan Praktis}

- Sebagai bahan masukan khususnya masyarakat Jawa maupun suku lainnya dalam mengetahui makna yang terdapat pada upacara perkawinan suatu suku bangsa khususnya masyarakat Jawa agar terciptanya keharmonisan dalam berumah tangga.

- Sebagai bahan masukan bagi tokoh adat, dan agama serta pemangku kepentingan lainya yang berkaitan 
dengan upacara perkawinan Adat dalam memahami budaya suku Jawa, khususnya dalam prosesi perkawinan.

\section{METODOLOGI PENELITIAN}

\section{Paradigma Penelitian}

Paradigma yang digunakan dalam penelitian ini adalah paradigma konstruktivistik. Paradigma ini memandang ilmu sosial sebagai analisis sistematis terhadap suatu tindakan sosial penuh makna (socially meaningful action) yang menggunakan pengamatan langsung dan rinci terhadap perilaku sosial secara alamiah, untuk memahami dan menafsirkan bagaimana para sosial menciptakan dan memelihara dunia sosial mereka. ( Hidayat, 2003:3).

\section{Metode Penelitian}

Dalam penelitian, peneliti menggunakan jenis penelitian kualitatif karena metode kualitatif sebagai prosedur penelitian yang menghasilkan data deskriptif berupa kata-kata tertulis atau lisan dari orangorang dan perilaku yang di amati untuk diarahkan pada latar dan individu yang holistic (utuh) (Moleong, 2009: 34).

\section{Sumber Data}
a. Data Primer
b. Data Sekunder

\section{Informan Penelitian}

Informan adalah bagian yang akan dipelajari dan diamati untuk diteliti sedangkan menurut Moleong Informan (Narasumber) penelitian adalah "Orang yang dimanfaatkan untuk memberikan informasi tentang situasi dan kondisi latar penelitian.Informan dalam penelitian ini didapatkan dari teknik Purposive sampling, menurut Tatang Mangguny daam Blognya, Purposive sampling adalah "pengambilan sampel secara sengaja sesuai dengan persyaratan yang diperlukan"(Sugiyono, 2014: 219).

\section{Teknik Pengumpulan Data}

1. Observasi (pengamatan) Partisipasi

2. Wawancara

3. Dokumentasi

\section{Analisis Data}

Menurut Matthew B.Miles dan A Michael tahap analisis data dalam penelitian kualitatif secara umum di mulai sejak ( Miles dkk, 2007: 246) :

1. Pengumpulan data

2. Reduksi data

3. Penyajian data (display data)

4. Penarikan kesimpulan serta verifikasi

\section{HASIL DAN PEMBAHASAN}

\section{Budaya}

Faktor budaya, berhubungan dengan nilai, norma dan aturan yang mempengaruhi perilaku komunikasi manusia yang meliputi pandangan dunia (agama), bahasa, dan sikap terhadap orang lain yang dipengaruhi oleh budaya individu atau budaya kolektif. Berdasarkan hasil wawancara mendalam dan observasi langsung yang 
dilakukan oleh peneliti, pengaruh faktor budaya dalam perkawinan beda budaya Jawa dan Pekal dalam aspek agama kedua etnis memiliki prinsip agama adalah hal utama dalam menetukan pilihan hidup/ pasangan, namun mereka menjelaskan berkaitan dengan komunikasi umum dengan orang lain dalam kehidupan seharihari agama tidak menjadi hambatan dalam komunikasi antar budaya. Hal serupa juga terlihat dari perkawinan beda etnis Jawa dan etnis Batak mengagap bahwa agama adalah hal yang prisip ketika mereka ingin menentukan pasangan hidup mereka, namun agama tidak menjadi hal yang prisip ketika mereka malakukan komunikasi antar buday secara umum.

Selain itu aspek yang selanjutnya adalah aspek bahasa, bahasa dalam komunikasi antar budaya perkawinan beda budaya baik Jawa- Pekal dan Jawa- Batak mereka menggunakan bahasa Indonesia selain itu mereka juga menggunakan mediator untuk menjembatani komunikasi tersebut, mediator dalam komunikasi perkawinan beda budaya ini adalah pemandu pengantin, selain dari itu mediator disini adalah tokoh masyarakat yang dituakan yang mana mereka lebih mengetahui budaya tersebut (sesepuh).

Aspek yang selanjutnya adalah sikap, perbedaan sikap pasti terjadi dalam etnis, Budaya yang diperoleh dan dimiliki seseorang sejak bayi sangat mempengaruhi cara seseorang tersebut dalam berpikir, berperilaku, dan berinteraksi atau berkomunikasi dengan orang lain (TubbsSylvia Moss, 1996:237). Oleh karena itu, ketika seseorang dipindahkan ke lingkungan beda budaya, dia tidak bisa serta merta meninggalkan pengaruh budaya yang melekat dalam dirinya di lingkungan yang baru. Hal itu terlihat dari perkawinan beda budaya etnis Jawa dan Pekal yang terlihat masih bingung dan tidak percaya diri ketika mereka ada dalam lingkungan etnis baru mereka lebih memilih diam ketika mereka tidak diajak berkomunikasi, namun hal itu hanya timbul di awal komunikasi, seiring berjalanya waktu mereka juga bisa memahami semua situasi yang baru. Selain itu hasil dari obesrvasi penelitaian penulis melihat adanya sebuah solidaritas kelompok dalam perkawinan beda budaya antara Jawa dan Pekal, mereka merasa mendapatkan hal yang positif dari perkawinan bedan etnis yaitu terjalinya silaturahim dan kekeluargaan yang baru dan menemukan saudra baru.

Seperti yang dijelaskan oleh De Vito dalam (liliweri 2001: 171) dalam komunikasi antar budaya yang efektif perasan positif dan dukungan adalah yang penting dilakukan. Perasaan positif ialah perasaan seorang komunikator bahwa pribadinya, komunikator lainya, serta 
situasi yang melibatkan keduanya sangat mendukung. Memberi dukungan ialah suatu situasi kondisi yang dialami komunikator dan komunikator lainya terbebas atmosfir ancaman, tidak dikritik dan ditantang, terlihat dari hasil observasi menunjukan walaupun ada muncul penggunaan budaya kolektif dari inforam Jawa dan Pekal namun persaan positif dan saling memberikan dukungan nampak dari kedua belah pihak, sehingga walaupun terjadi perbedaan nilai sikap dan prilaku, dengan seiringnya waktu berjalan mereka akan mengalami kenyamaan dalam berkomunikasi dengan etnis yang berbeda.

Hal yang berbeda terlihat dari pasangan beda budaya etnis Jawa dan Batak, kedua pasangan ini tidak dipengaruhi budaya kolektif mereka, namun etnis Batak menilai lingkungan baru dalam waktu yang lama dapat mengubah sikap dalam berkomunikasi, lingkungan baru itu adalah lingkungan orang Jawa, namun demikian perubahan sikap itu tidak berkaitan dengan perinsip mereka etnis Batak yang tegas.

\section{Sosiobudaya}

Faktor sosiobudaya yang dijelaskan dalam model Gudykunts dan Kim menyangkut proses penataan sosial (social ordering process) yang berkembang berdasarkan interaksi dengan orang lain ketika pola-pola perilaku menjadi konsisten dengan berjalannya waktu.
Seperti yang diungkap oleh De Vito dalam (liliweri 2001: 171) terkait komunikasi antar budaya yang efektif maka harus memelihara keseimbangan yaitu suatu suasana yang adil antara komunikator dan komunikan dalam hal kesempatan yang sama untuk berpikir, merasa dan bertindak. Dari observasi yang penulis lakukan dalam perkawinan beda budaya antara Jawa dan Pekal serta Jawa dan Batak terlihat mereka saling menjaga keseimbangan tidak mendominasi menggunakan salah satu dari budaya etnis mereka namun mereka sepakat akan menggunakan budaya apa pun selagi itu memang untuk kebaikan keluarga kedepanya.

\section{Psikobudaya}

Faktor piskobudaya mencakup proses penataan pribadi (personal ordering process) proses penataan pribadi ini adalah proses yang memberi stabilitas pada proses psikologis.

Seperti yang diungkap oleh De Vito dalam (liliweri 2001: 171) terkait komunikasi antar budaya yang efektif maka empati juga menjadi hal yang akan mentukan arah komunikasi antar budaya yang efektif. Terkait hal ini, Lilian Chaney (2004:11) menyatakan bahwa agar komunikasi berlangsung lebih bermakna atau efektif, individu-individu yang terlibat dalam komunikasi harus mampu dan mau berempati dan berniat mengurangi tingkat 
ketidak- pastian dalam komunikasi. Bila, salah satu peserta komunikasi mampu dan mau melanjutkan komunikasi, maka ia harus berusaha masuk menuju titik pemahaman (convergence) sehingga tercapai komunikasi efektif. Bila tidak, maka ia akan menghenti- kan komunikasi (divergence) sehingga komunikasi menjadi tidak efektif. Dari observasi yang penulis lakukan dalam perkawinan beda budaya antara Jawa dan Pekal serta Jawa dan Batak terlihat mereka saling menjaga empati tersebut, Sehingga, pada prakteknya semua informan menyatakan saling memahami dan menghormati antar etnis, yang memiliki perbedaan masing-masing.

\section{Lingkungan}

Salah satu unsur yang melengkapi model Gudykunst \& Kim adalah faktor lingkungan. Lingkungan mempengaruhi kita menyandi dan menyandi balik pesan .Lokasi geografis, iklim, situasi arsitektural (lingkungn fisik) dan presepsi kita atas lingkungan tersebut, mempengaruhi cara kita untuk menafsirkan rangsangan yang datang dan prediksi yang kita buat mengenai prilaku orang lain . Dari hasil obeservasi yang peneliti lakukan melihat bahwa pengaruh lingkungan dalam komunikasi antar budaya dalam perkawainan beda budaya ini muncul, perkawinan etnis Jawa dan Pekal mempunyai perbedaan pandangan etnis
Jawa memandang bahwa penggunaan adat istiadat dalam prosesi adat adalah suatu usaha untuk melesetarikan budaya dan memperkenalkan budayanya dengan etnis lain, sedangkan pandagan etnis Pekal menilai bahwa perkawinan yang paling utama adalah mencari legalitas perkawinan baik agama dan Negara, sedangkan adat istiadat yang diggunakan adalah faktor pelengkap dalam acara perkawinan tersebut.

Demikian dengan perkawinan etnis Jawa dan Batak juga faktor lingkungan juga muncul dalam perkawinan tersebut. Etnis Jawa menyatakan belum merasakan kepuasaan hati mereka ketika mereka tidak menggunkan adat istiadat Jawa, walaupun kenyataan mereka tidak menggunkan seluruh dari rangkaian adat istiadat tersebut sesuai dengan yang aslinya. Namun demikian padangan etnis Batak yang menilai bahwa etnis Jawa terlalu rumit dalam menggunkan adat, hal tersebut dijelaskan dari penentuan hari pernikahan, untuk menentukan etnis Jawa memiliki metode tersendiri yang menurut etnis Batak hal itu terlalu susah. Selain dari itu dalam pertungan etnis Batak tidak pernah melegalkan tentang sanksi adat ketika melanggar pertungan tersebut, pasalnya etnis Jawa menggunkan sanksi tersebut ketika salah satu dari mereka menggalkan pertungan yang sudah disepakati dengan 
membayar denda sanksi adat sebesar 45 juta rupiah, selain itu etnis Batak juga menilai segala prosesi dalam etnis Jawa dikaitkan dengan hal-hal mitos. Perbedaan pandagan tentang perkawinan ini karena didasari oleh perbedaan budaya oleh karena itu orang lain memiliki presepsi dan orientasi yang berbeda terhadap lingkungan, dan mereka mungkin menafsirkan prilaku dengan cara yang berbeda walau dalam keadaan situasi yang sama yaitu dalam situsai perkawinan.

Berdasarkan hasilnya penelitian yang telah dijabarkan di atas maka komunikasi antar budaya dalam perkawinan adat Jawa terhadap perkawinan beda budaya yaitu Jawa-Pekal dan Jawa- Batak dengan menggunkan kacamata model Gudykunts dan Kim dapat dilihat sebagai berikut, perkawinan antara etnis Jawa dan Pekal dilihat dari fakor budaya munculnya perbedaan budaya kolektif yang mempengaruhi proses komunikasi antar budaya, namun kendala itu hanya muncul diawal komunikasi saja selebihnya setelah terjadi pendekatan budaya kolektif itu hilang dengan sendirinya. Ditinjau dari faktor sosiobudaya dalam perkawinan etnis Jawa dan Pekal tidak terlihat kendala tersebut, mereka menggunkan nilai secara universal saling menghargai dan menghormati. Selanjutnya ditinjau dari faktor psikobudaya, setriotip dan etnosentrisme terlihat muncul dari kedua etnis namun demikian setrotip dan etnosentrisme tersebut hanya dalam batas pemikiran dan tidak dalam bentuk tindakan sehingga tidak mempengaruhi dalam proses komunikasi.

Adapun hasil penelitian penulis apabila digambarkan maka akan menghasilkan model sebagai berikut :

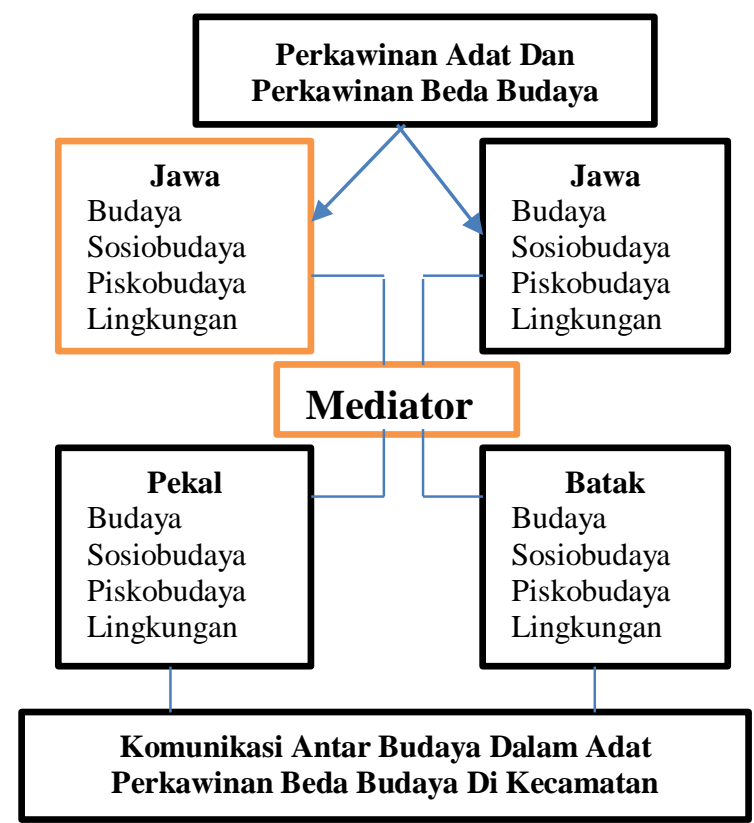

Gambar : Model Komunikasi Antarbudaya

Gambar diatas menunjukan bahwa dalam proses perkawinan beda budaya di kecamatan Ketahun ada peran mediator dalam menjembatani terjadinya komunikasi tersebut. perbedaan konsep budaya dari kedua belah pihak terkadang membuat kendala dalam melakukan proses komunikasi, khusunya psikobudaya lebih nampak terlihat dalam proses komunikasi tersebut, dengan adanya pemahaman yang diberikan mediator mereka dari kedua 
budaya timbul rasa empati dan menghormati kepada budaya pasangan.

Dalam model Gudykunts dan Kim belum digambarkan adanya peran mediator tersebut, dalam model ini hanya mengkaji beberapa dimensi budaya, sosiobudaya, psikobudaya dan lingkungan. Hasil penelitian penulis di Kecamatan Ketahun menunjukan ada peran mediator dalam proses perkawinan beda budaya Jawa dengan Pekal dan Jawa dengan Batak, mediator disini terdiri dari Tokoh masyarkat, adat dan perias pengantin.

\section{PENUTUP}

\section{Kesimpulan}

1. Komunikasi antar budaya dalam perkawinan etnis yang berbeda ditinjau dari Faktor Budaya: perbedaan agama tidak nampak menjadi sebuah kendala karena mereka juga satu akidah dan satu agama. Dari bahasa tidak menjadi kendala karena mereka menggunakan Mediator dan menggunkan bahasa Indonesia. Perbedaan sikap terlihat menjadi sebuah kendala awal dalam berkomunikasi namun setelah adanya pemahaman yng diberikan seorang mediator akhirnya juga mereka memahaminya. Faktor Sosiobudaya: faktor ini tidak terlihat menjadi kendala karena dari kedua belah pihak tidak memaksakan untuk menggunkan salah satu adat saja mereka saling menggunkan kedua adat baik dalam pra perkawinan ataupun pasca perkawinan selepas semua itu bik untuk kedepanya. Faktor Psikobudaya: hambatan ini timbul karena stereotip, etnosentrisme dan prasangka tentang masyarakat Jawa yang terlalu rumit dan terlalu banyak adat istiadat selain itu mereka menngangap bahwa adat istiadat Jawa selalu adat kaitanya dengan mitos, namun demikian faktor psikobudaya ini hanya sebatas dalam pemikiran bukan dalam bentuk tindakan. Faktor Lingkungan: perbedaan lingkungan muncul dalam bentuk orientasi tentang waktu dan makna perkawinan.

2. Teori Gudykunt dan Kim yang terdiri dari 4 faktor diantaranya budaya, sosiobudaya, piskobudaya dan lingkungan yang lebih dominan muncul dalam perkawian beda budaya Jawa-Pekal dan Jawa- Batak adalah faktor Piskobudaya. namun demikian faktor ini tidak pada intensitas yang negatif yang membahayakan dalam proses komunikasi tersebut. Selain itu mediator juga terlihat dalam proses perkawinan beda budaya ini dalam menjembatani proses berjalanya komunikasi tersebut, mediator disini adalah para tokoh masyarakat dan perias pengantin. 


\section{Saran}

1. Untuk calon pengantin yang akan melangsungkan perkawinan beda budaya, hendaknya harus saling memahami dan saling mengenal terlebih dahulu adat masing-masing agar terciptanya komunikasi anatar budaya yang efektif, dan tidak ada lagi konflik antar budaya khususnya dalam perkawinan beda budaya.

2. Untuk masyarakat Bengkulu Utara khususnya masyarakat kecamatan Ketahun, adat perkawinan disetiap suku hendaknya selalu digunakan dalam acara adat dan menjadi tradisi setiap sukunya agar tetap lesatari dan tidak punah.

3. Dapat memberikan dan menambah masukan dalam rangka pelaksanaan akademik khususnya di bidang pengembangan ilmu komunikasi serta dapat di gunakan sebagai bahan penelitian lebih lanjut yang berhubungan dengan penelitian ini.

\section{DAFTAR PUSTAKA}

Amri Marzali, 2009, Antropologi \& Pembangunan Indonesia, Jakarta: Kencana.

Liliweri. A .2003,Dasar-Dasar Komunikasi Antarbudaya, Pustaka Pelajar: Yogyakarta.
DeVito, Joseph A. The Interpersonal Communication Book (Ninth Edition). New York: Addison Wesley Longman, Inc., 2001.

Deddy Mulyana, 2011.Ilmu Komunikasi.

Bandung: PT. Rosdakarya.

Deddy Mulyana, Ilmu Komunikasi Suatu Pengantar (Bandung: Remaja Rosdakarya, 2010).

Hariwijaya, Muhammad. 2008. Tata Cara Penyelenggaraan Perkawinan Adat Jawa. Yogyakarta: Hanggar Kreator.

H.M.A. Tihami dan Soehari Sahrani, Figh Munakahat Kajian Fiqh Nikah Lengkap(Jakarta: Rajawali Pers, 2009).

Hamidin, Buku Pintar Perkawinan Nusantara, (Yogyakarta: DIVA Press,Cet 1, 2002).

Iskandar Wirjokusumo, Soemardji Anshori,

Metode Penelitian Kualitatif Bidang

Ilmu- Ilmu Sosial Humaniora,. Unesa

University Press, 2009.

Kriyantono, Rachmat.2006. Teknik Praktis Riset Komunikasi.Jakarta: Kencana.

Karmadi Agus Dono dkk, MENGENAL PENGANTIN TRADISIONAL DAERAH JAWA TENGAH, (Semarang:

Departemen Pendidikan dan Kebudayaan Direktorat Jenderal Kebudayaan Museum “Ronggowarsito", 1997).

Liliweri, Alo. 2001. Gatra-Gatra Komunikasi Antarbudaya. Yogyakarta: Pustaka Pelajar. 
Lubis Lusiana Andiani. Pemahaman Praktis

Komunikasi Antarbudaya.2012. Medan . Usu Pers.

Lustig, Myron, dan Jolene Koester. Intercultural Competence, Interpersonal Communication Across Cultures (Fourth Edition). USA: Allyn \& Bacon Pub., 2003.

Lexy Moleong J, Metodologi Penelitian Kualitatif .Bandung: PT.Rosda Karya, 2009.

Mulyana, Deddy dan Jalaluddin Rakhmat.

2005. Komunikasi Antar Budaya. Bandung: PT. Remaja Rosdakarya.

Martin, Judith dan Thomas K. Nakayama. 2007. Intercultural Communication in Contexts. New York:Mc Graw Hill International.

Mardani, Hukum Perkawinan Islam Di Dunia Islam Moderen (Yogyakarta: Graha Ilmu, 2011),

Miles, Mattew B dan A. Michael Huberman. (2007). Analisis Data Kualitatif, Buku sumber tentang metode-metode baru. Jakarta:Universitas Indonesia Press

Rahardjo, Turnomo. Menghargai Perbedaan Kultural: Mindfulness dalam Komunikasi Antaretnis. Yogyakarta: Pustaka Pelajar, 2005.

Samovar, Larry A., Richard R Porter \& Edwin R McDaniel. 2010. Communication Between Cultures, 7th Edition. USA: Wadsworth Cengage Learning.
Sugiyono. 2014. Metode Penelitian Kuantitatif, Kualitatif, dan $R$ \& G. Alfabeta, Cv. Bandung.

Sugiyono. (2009). Metode Penelitian Bisnis (Pendekatan Kuantitatif, Kualitatif, dan $R \& D)$. Bandung: Alfabeta.

Sumarsono, Tata Upacara Pengantin Adat Jawa, ( Yogyakarta: $N^{\top}$ '2007)

Tubbs dan Moss, Conrad, 2005.IlmuKomunikasi, Buku pertama, Edisi Bahasa Indonesia,Jakarta PT. Gramedia.

Wahyudi, Eka DKK. MADURA: Masyarakat, Budaya, Media, dan Politik. Penerbit: Puskakom Publik bekerjasama dengan Penerbit Elmatera 2015.

\section{Jurnal ,Tesis dan Undang-undang:}

Jom FISIP Universitas Riau Folume 2 NO. 2 Oktober 2015.

Lusiana Lubis dari Universitas Sumatera Utara pada tahun 2012 yang berjudul "Komunikasi Antarbudaya dalam Proses Asimilasi Pada Pernikahan Campuran Suku Batak Toba-Tionghoa di kota Medan.

Rulliyanti Puspowardhani. Program Studi Magister Ilmu Komunikasi Program Pascasarjana Universitas Sebelas Maret Surakarta 2008

P. Hariyono .Kultur Cina dan Jawa: Pemahaman Menuju Asimilasi Kultural (1993). 
Mia Retno Prabowo .Penyesuaian Perkawinan Pada Pasangan Yang Berlatar Belakang Etnis Batak Dan Etnis Jawa Fakultas Psikologi, Universitas Gunadarma. 2007. Undang-undang Nomor 1 tahun 1974 pasa 1

\section{Internet:}

(https://callmefadh.wordpress.com/2016/03/15 / mengenal-lebih- dalam-berbagai-jenissuku-batak-dan-budayanya/ diakses tanggal 10-03-2018).

(http://1838.stietrianandra.web.id/id3/2474237 0/Pekal_116896_trianandra_1838stietrianandra.html diakses 10-03-2018). 